\title{
Further Discussion on the Construction of Ethics of Professional Accountants
}

\author{
Yong Cheng \\ School of Business Administration, Shenyang University \\ No.54, Lianhe Road, Dadong District, Shenyang 110041, China \\ Tel: +86-135-5570-4468 E-mail: 19781978cy@163.com
}

Received: February 3, 2012

Accepted: February 27, 2012 Published: May 15, 2012

doi:10.5430/ijba.v3n3p28

URL: http://dx.doi.org/10.5430/ijba.v3n3p28

\begin{abstract}
Any country is facing the problem of ethics of professional accountants, which also has been a focus of accounting theories for many years. Especially since the financial crisis in 2008 and the recession of world economy, business has been difficult, which makes the ethics of professional accountants more important. In perspective of business ethics, the author discusses the characteristics and the structure of ethics of professional accountants, locating the barriers for the construction of ethics of professional accountants and relevant reasons, and proposing the way for establishing the system of ethics of professional accountants.
\end{abstract}

Keywords: Business Ethics, Ethics of Professional Accountants, Discussion

Accounting is an important part of economic management. The accounting work, including the various types of materials reflecting the financing conditions and business operations of accounting entity, is the main source of information for the accounting entity, investors, creditors, banks, and government. The standard accounting practices and reliable accounting information can help users of accounting information to make the right decision. The more developed the economy is, the more important the accounting is. Along with the accelerating process of integration of world economy, the closer trade between countries, the more popular trans-national investment, and the more frequent information exchange, the accounting rules tends to be closer to the international accounting code. As a result, the credibility crisis of accounting and the distortion of accounting information would be the serious problems in front of all countries. The quality of accounting information draws the social attentions to a great degree. Therefore, to improve the quality of accounting information has become a difficult problem of the accounting field, the economic field, and even the whole society.

On the surface, the accounting credibility crisis and the distortion of accounting information are caused by worse social economic environment, inadequate laws and regulations, poor enforcement and ineffective punishment, what are incapable of constraining the bad behaviors of accountants. A deeper reason lies in accountants themselves, in peoples' decaying morals. The accounting credibility crisis particularly reflects the absence of professional ethics of accountants. Laws can only deal with visual illegal activities but not bad thoughts or behaviors. Only by morals, can it achieve the supervision by self-discipline and heteronomy. Combining laws and morals together can achieve the admirable result, fundamentally solving the problems of accounting.

The fundamental guarantee for the quality improvement of accounting work is to build up the moral system of professional accountants, to improve the comprehensive quality of accountants, to implement relevant laws and regulations, and to improve the basic work of accounting.

\section{An Overview of Theories of Building Ethics of Professional Accountants in Perspective of Business Ethics}

\subsection{An Interpretation of the Construction of Ethics of Professional Accountants in Perspective of Business Ethics}

Business ethics generally refers to people's intention of following morals and codes of behaviors as individuals get along with each other in enterprise. Business ethics is a part of general strategy, and also the ethics design by top management and the choice and orientation of ethical level, and more the long-term development program in perspective of ethics. In short, business ethics is the intention of enterprise examining, mining, and distributing ethical resources with a strategic vision, in the hope of achieving the general strategic goal. Ethics of professional accountants is the professional codes and norms supposed to be followed by accountants in professional activities, reflecting the professional characteristics of 
accountants, and adjusting the professional relations. The specific requirements for ethics of professional accountants mainly focus on seven aspects: dedication to the job, honesty and credibility, self-discipline and clean, objectiveness and fairness, adhering to principles, improving techniques, and participating in management. Therefore, in a complicated economic environment, the construction of ethics of professional accountants in perspective of business ethics is the activity of accountants following professional codes and norms as they handle the interest relationships between individuals and enterprise, enterprise and society, operators and investors.

\subsection{The Characteristics of the Construction of Ethics of Professional Accountants in Perspective of Business Ethics}

\subsubsection{Distinct Political and Binding Characteristic}

As there is an interest conflict, seduced by business ethics, accountants may become money worshipers who get rid of rules and confuse the right direction. Without noble professional morals or in capable of adhering to principles, accountants would damage the interests of business investors. If the ethics of professional accountants in perspective of business ethics emphasizes more on the importance of morals, it will help to make the professional accounting more human. Accountants are the master of accounting. The accounting must emphasize the regularity and principles, defining a clear line for "what should be done". Under the influence of business ethics, accountants need to improve their moral levels.

\subsubsection{Selfish and Honest Characteristic}

Accounting is closely connected with money, finance, and materials. Only when accountants deeply understand the principles of morals, can they be clean and self-discipline, law-abiding, and selfless, giving the exclusive priority to the interests of enterprise. They regulate and restrain their thoughts and behaviors, building a wall in mind to prevent corruptions. Under any conditions at any time, they maintain the cool brain and withstand various tests.

\subsubsection{Service and Highly Interest-Related Characteristic}

Serving the enterprise is the fundamental part of ethics of professionals, which determines the characteristics of accountants being service and highly interest-related. There is always a specific relationship between people in society, namely the relationship of mutual service and related interests. Under this circumstance, it's one for all and all for one. In market economy, it is very important for accountants mastering themselves and finding a balance in business ethics and professional ethics.

\subsection{The Necessity of Building the Ethics of Professional Accountants in Perspective of Business Enterprise}

1.3.1 Changes of Micro Environment Make the Enterprise to Build the Ethics of Professional Accountants in Perspective of Business Ethics

Today since the interest relationship and the interpersonal relationship between accountants are complex, the ethics and values of accountants have undergone profound changes. Some original morals could not adapt to the new conditions. Especially as the economic interests conflict with ethics, a large number of accountants may feel moral confusion, confronted by moral conflicts, and finally causing moral anomie. In the accounting field, accounting information is distorted seriously and false accounting prevails. Many accounting problems, such as the factory director-determined profits, the chief-determined costs, the manager-determined benefits, the overall low business performance, and the vulnerable accounting management, seriously damage the interests of social public.

1.3.2 Changes of Macro-Environment Make the Enterprise to Build the Ethics of Professional Accountants in Perspective of Business Ethics

The level of ethics of professional accountants is based on whether the environment is good or bad. In order to form a complete and effective ethical system of professional accountants, it is necessary to build a good external environment. The external environment is the fundamental guarantee for the construction of ethics of professional accountants during the period of social transformation. To strengthen the construction of ethics of professional accountants is also an important part in order to combat corruption and rectify unhealthy tendencies in economic field. Under the complicated accounting environment with more serious moral conflicts, the enterprise seeks for the root of unethical phenomena with business ethics standards, avoid and stop the unethical phenomena as much as possible. To build an ethical system of professional accountants becomes an essential task right now.

\section{The Mechanism and the Influence of Building the Ethics of Professional Accountants in Perspective of Business Ethics}

\subsection{The Mechanism of Building the Ethics of Professional Accountants in Perspective of Business Ethics}

2.1.1 The Correlation between Business Ethics and the Construction of Ethics of Professional Accountants 
The correlation between business ethics and the construction of ethics of professional accountants exists naturally. The construction of ethics of professional accountants is derived from business ethics. Accounting has a close relationship with business ethics since its birth. Along with the development of science and technology, market competition is increasingly fierce, and economic and commercial behaviors affect the enterprise more significantly. Accounting is not simple enterprise activities any more, but widespread social activities. The ethics of professional accountants is subjective to business ethics. The latter penetrates in all fields of business activities. Accountants' material and spiritual needs for employment, promotion, and welfare are subjective to business ethics. The ethics of professional accountants conducts an opposite effect on business ethics. Accountants master the enterprise's information of financial conditions, operation results, and cash flow. The effective construction of ethics of professional accountants can not only disclose the positive side of business ethics fairly, but also avoid the negative side.

\subsubsection{The Architecture of the Construction of the Ethics of Professional Accountants in Perspective of Business Ethics}

The architecture of the construction of the ethics of professional accountants shows new characteristics in perspective of business ethics. The basic scope of architecture includes the features of building ethics of professional accountants and the evolution, the reasons for the decline of morals, the ethics and morals in enterprise culture, the ways for institutional innovation of enterprise credit management and the contents. The extensive scope of architecture is to analyze the influences of market economy on ethics of professional accountants, proposing the self-discipline mechanism and the heteronomy mechanism for the ethics of professional accountants.

\subsection{The Influences of the Construction of Ethics of Professional Accountants in Perspective of Business Ethics}

Ethics of professional accountants can not only help to enhance people's trust in accountants and regulate the professional behaviors of accountants, but also help to protect the economic interests of all sectors of society. However, business ethics and professional ethics increasingly become the focus of public attention. All the accounting frauds disclosed in Enron in the United States, Sony Corp. in Japan, and Shell in Europe reveal to the public the dark side of accounting. Accountants may compose false financial information, or conceal the real accounting information, or delay the information disclosure, or exaggerate the assets or profits, fooling all investors. The false profits and costs in these cases hit the top record in history. These facts are quite a shock in the world. Accounting firms that provide services for enterprises' accounting fraud include five well-known accounting firms: Arthur Andersen, KPMG, Price Waterhouse Coopers, Deloitte, and Ernst \& Young. In China, accounting is also facing a serious crisis of credibility. According to a questionnaire survey of more than one thousand accountants in work, $16.87 \%$ of accountants argue to adhering to principles. $61.27 \%$ of accountants think that they should not only obey the orders of managers, but also properly handle the accounting problems. $21.86 \%$ of accountants think that they should completely obey the orders of managers. Some accountants steal from the enterprise for the sake of their own interests, completely losing the professional ethics, and seriously ruining the image of enterprise and the interests of the public. Analyses show: to examine the construction of ethics of professional accountants in perspective of business ethics has a more far-reaching effect on enterprises and society, with more significant meanings.

\section{The Barriers of and Reasons for the Construction of Ethics of Professional Accountants in Perspective of Business Ethics}

\subsection{The Ethics of Professional Accountants Needs More Improved Normative System and Implementation Mechanism}

The normative system and the implementation mechanism of ethics of professional accountants in China are not systematic or complete, what mainly focus on two aspects: the ethics of professional accountants has no clear levels; the evaluation system and the punishment mechanism have no sufficient rigidity. Ethics of professional accountants in China is basically scattered among various accounting regulations, not in one system or arranged by levels. For behaviors violating ethics of professional accountants, the punishment is too light or even there is no punishment at all, which makes these behaviors profitable. Plus the unobvious interests from following the ethics of professional accountants, many accountants may break into the restricted area. Therefore, the undeveloped normative system and implementation mechanism of ethics of professional accountants encourage the misbehaviors of accountants as a matter of fact.

\subsection{Accounting Management is not in Place so that the Supervision and Inspection tend to be Weak}

The punishment for behaviors violating the ethics of professional accountants is weak and the discipline is loose. The rewards for good behaviors and the punishments for bad behaviors are not clearly defined. There is no example for following the ethics of professional accountants. As a result, accountants may hold a wrong understanding, neglecting the nature of being accountants, which is to devote them to fair accounting. Plus the weak supervision and inspection done by enterprise leaders, it makes accountants betray the ethics of professional accountants with a high probability. 
Furthermore, the inappropriate and insufficient management causes weak supervision and inspection.

\subsection{Accountants Pay Less Attention to Professional Ethics and the Unethical Behaviors Are Serious}

In the society with serious interest conflicts, as accountants deal with the interest conflict between the enterprise and the society, they cannot adhere to the right principles. They even false or alter the accounting books and statements, resulting in various inconsistent accounting. As accountants conflict with auditors, most of them agree that covering problems and coping with social supervision and taxation are their supposed tasks.

\subsection{Qualities of Accountants Are Low and They Lack Of Education of Professional Ethics}

In China's accounting education, the ethics has not been given the high priority. Many students seem to have narrow knowledge, poor bases, and weak abilities. They may act as declining morals and short of responsibilities. Besides, accountants cannot resist unhealthy practices with self consciousness in work. They are under the influences of powers, posts, and even the interests, which makes them easier to disobey the fundamental principles of accounting laws.

\subsection{The Unhealthy Social Trends Shake the Self-Regulatory Mechanism of Accountants}

As people are in pursuit of material interests, the consciousness of individualism, egoism, and hedonism weakens the collectivism and people's full dedication to the public, resulting in the frequent appearances of ugly social phenomena. The unhealthy social trends shake the self-regulatory mechanism of accountants, and thus affect their orientation to values.

\section{Create a Good Atmosphere for Business Ethics in Order to Reach the Path for the Construction of Ethics of Professional Accountants}

\subsection{Improve the Reward-Punishment Mechanism of Professional Ethics and Create a Good Atmosphere for Business Ethics}

A good atmosphere for business ethics can promote the construction of ethics of professional accountants. By learning from international practices, we can improve the ethical system of professional accountants, build the assessment and reward mechanism, construct the record-tracking system and the supervision organization, make up and release relevant specific accounting principles concerning merge of enterprises, combined accounting statements, and foreign currency translation. Meanwhile, we must build and improve the assessment and reward mechanism for professional ethics of accountants, creating a good work environment for accountants.

\subsection{Strengthen the Supervision and Improve the Effectiveness of Regulatory, and Create a Good Atmosphere for Business} Ethics

Strengthen the government supervision, improve the industrial self-regulation, and use social supervising powers, such as the media and the public. The financial department should not only support the accounting association to carry out the work of self-regulatory of accountants, but also strengthen the annual inspection of Accounting Qualification Certificate, ensuring that every accountant join in continuing education and improve their qualities. Meanwhile, enhance the coordinative management among functional departments, such as finance, auditing, taxation, and supervision, and form a strong exterior supervision mechanism. Examine whether accountants follow the professional ethics and forbid the cheating behaviors as much as possible. Punish the unprofessional accountants and the accountants with misbehaviors strictly and even withdraw their licenses under certain serious conditions.

\subsection{Strengthen the Construction of Ethics of Professional Accountants in Perspective of Business Ethics and Enhance the} Construction of Internal Control System

Make the professional accounting association play its role in constituting practical professional ethics for accountants. Establish the obligations and responsibilities of accountants and help accountants hold noble professional ethics. At the same time, the enterprise should strengthen the construction of internal accounting management system, which is an important way for improving business management and economic efficiency. Build a complete internal control system and stimulate accountants' enthusiasm for accounting. Prevent against accountants betraying the professional ethics in daily work. Besides, set up a mechanism for assessment, competition, rewards, and restraints to improve accounting quality and efficiency.

\subsection{Strengthen the Team Building and Improve the Professional Ethics of Accountants in Perspective of Business Ethics}

Ethics is more important than techniques or knowledge. Accountants are not only technical experts but also ethical experts. Every accountant should possess the quality and belief of pursuit for professional ethics. Accounting education should not only focus on techniques, but also convey the spirit of dedication and the moral standards. It should pay more attention to the improvement of professional ethics of accountants in work. Accountants should improve their 
professional ethics consciously, enhance the sense of mission, and resist bad influences and interferences from the society.

4.5 Establish a Good Social Atmosphere and Optimize the Construction of External Environment for Ethics of Professional Accountants in Perspective of Business Ethics

A good social atmosphere can help to optimize the environment of business ethics and a better environment of business ethics and help to achieve the effective construction of ethics of professional accountants. It is necessary to create an environment with perfect laws and institutions for accountants. To purify the ethical environment for accountants not only needs the efforts of accounting field, but also needs the cooperation and coordination of social communities.

\section{References}

Jia, J. (2009). The current ethics of professional accountants and relevant measures. Silicon Valley. No.2: pp193.

International Federation of Accountants (IFAC). Code of Ethics of Professional Accountants.

Shao, S. \& Shao, D. (2009). On current conditions of professional accountants ethics and measures for improvement in China. Science \& Technology Information. No.4: pp295.

Zhou, J. (2008). On the ethical strategy of enterprise. Studies in Ethics. No.4: pp47. 